\title{
Studies of Naturally Infected Babesiosis and Its Effect on Some Hematological and Biochemical Parameters in Cattle in Qena, Egypt
}

\author{
Mohamed Saied MM* \\ General Organization of Veterinary Service, Egypt \\ Submission: September 26, 2017; Published: October 31, 2017 \\ *Corresponding author: Mohamed Saied MM, PH.D., Veterinarian at GOVS (General Organization of Veterinary Service), Egypt, \\ Email: mosmvet@yahoo.com
}

\begin{abstract}
In the present study, 40 Egyptian cattle infected with babesiosis and 10 healthy (as control) were used as animal material Hematological findings that were observed with domestic animals in connection with blood parasite infections are very essential. In this study it was demonstrated that value of hematological parameters of the group, compromising infected animals, were relatively lower compared to control group parameters he infected animal showing decrease in RBC's counts, WBC's counts, an increase in phosphorus, decrease in calcium. Serum level of aspartame aminotransferases (AST) showed significant increase in babesiosis, while the Serum level of alanine (ALT) was significantly increased in Ababesiosis. Serum level of iron and copper suffered from babesiosis showed significant increase of both iron and copper serum levels. The aim of this study was to ascertain the effect of babesiosis on hematological parameters and several mineral levels.
\end{abstract}

Keywords: Cattle; Babesiaovis; Hematology; Mineral substances

\section{Introduction}

Babesiosis is a protozoan disease, which is generally characterized with high fever $\left(40-41^{\circ} \mathrm{C}\right)$, anorexia, weight loss, ruminal atony, dyspnoe, red water urine (haemoglobinuria) and jaundice, of sheep, goat, cattle, horse, dog, and cats. emaciation, anemia, various degrees of jaundice (icterus) from paleness in mild cases to severe yellow discoloration of conjunctiva and vaginal mucous membranes in more progress cases., The vector places itself in animal's erythrocytes and Babesia forms can vary as pear-shaped, round and elongated.

The most common species that causes infection on cattle are in Egypt. Babesia bigemina, Babesia divergens, Babesia bovis babesia major. Two species, B. bigemina and B. bovis, have a considerable impact on cattle health and productivity in tropical and subtropical countries [1-8]. The mucous membranes are first hyperaemic, but at the later stages, they become icteric and the color changes to the pallor of anemia. Primary cause of anemia is due to intravascular haemolysis and rate of destruction of erythrocytes and capacity of erythropoiesis are the main denominators of the occurrence and intensity of the anemia [912].

In Egypt, bovine babesiosis is caused mainly by B. bigemina and $B$. bovis and considered as the most important and endemic parasitic disease affecting cattle [8,13]. Most often owners are trying to describe the clinical appearance of their animals using less informative symptoms, which often accompanies most diseases. Only few owners are able to describe symptoms, which could be pathognostic initially to babesiosis, and let the veterinarian to apply purposely one or more tests.

\section{Material and Method}

Forty (40) Egyptian cattle infected with babesiosis and ten (10) healthy (as control) were used as animal materials. Blood samples were collected from the jugular vein into EDTAcontaining tubes from 50 animals (40 cattle infected and 10 cattle as controls) of both sexes and aged 2-5 years, and were originating from different villages. The animals were examined at the Veterinary unit.

The control group (10 cattle) was carefully examined clinically and parasitological and found healthy and free from external, internal, and hemoparasites. Approximately $10 \mathrm{ml}$ of blood was taken from the jugular vein of all animals with a syringe containing EDTA. The blood samples were subjected to hematological parameters analysis $[14,15]$.

\section{Clinical examination}

Animals were subjected to clinical and hematological examinations at Veterinary unit. The filed-exposed group showed various degrees of bovine babesiosis such as high fever $\left(>40{ }^{\circ} \mathrm{C}\right)$, anorexia, hemoglobinuria (bloody urine), anemia, and 
jaundice. They were also infested with ticks to various degrees. The control group was examined thoroughly for presence of any abnormal clinical changes and external parasites, and was thoroughly examined by different laboratory techniques such as direct smear, flotation, sedimentation and Barmen's techniques and blood film to confirm the absence of any internal parasites.

\section{Results}

\section{Clinical Findings}

Cattle infected with B. bovis showed typical clinical signs of babesiosis. Briefly, highly rise in body temperature (40$41.5{ }^{\circ} \mathrm{C}$ ), conjunctive and vaginal mucous membranes were anemic and the clinical severity was ranged from paleness in mild cases to severe yellow discoloration (icterus) in more progressive cases, red to dark red urine (coffee-color) urine, hemoglobin urea was common sign in cattle with severe clinical manifestation and accelerated heart and respiratory rates. Some cases showed nervous manifestations in advanced stages such as in coordination and head pressing. Various degrees of tick infestations were present around groins, horns, Intermandibular space, and ears.

\section{Hematological Findings}

Giemsa-stained blood smears from $B$. bovis infected animals showed intra-erythrocyticpiroplasms of $B$. bovis that were in the form of pyri form or pear-shaped.

The mean values of RBCs, hemoglobin amount, PCV \%, WBCs, and differential leucocytes count are listed in. Briefly, the important findings can be summarized as follows; there is a clear significant difference in the hematological parameters between $B$. bovis infected buffaloes and B. bovis infected cattle in comparison to control group at P-value $(\leq 0.01)$ and $(\leq$ 0.001),respectively

\section{Discussion}

Tick-borne diseases have a negative effect on livestock health [16]. In this study, Babesia infection was confirmed via light microscopy examination. Presence of pear shape piroplasmsinside RBCs is confirmative of diagnosis especially in acute stages of the disease [17].

\section{Clinical findings}

The observed clinical findings in cattle with babesiosis such as fever, dark brown to coffee urine, pale mucous membranes with empty episcleral blood vessels with reduced appetite could be attributed to severe haemolytic process associated the presence of Babesia sp. inside the red blood cells $[18,19]$ supported this view.

\section{Hematological findings}

Leucogram showed significant decrease $(\mathrm{P}<0.001)$ in total leucocytes count and nuetrophil. Normocytic normochromic anemia observed in cattle with babesiosis which could be attributed to intravascular haemolysis of red blood cells [20] supported this view. Insignificant changes in total leucocytic count in total leucocytes count in cattle with babesiosis, while there was significant increase in lymphocytes and monocytes associated with significant decrease $(\mathrm{P}<0.001)$ in nuetrophils. This could be explained as the breakdown of red blood cells by Babesia sp. [21-24]. Even in animals which recover spontaneously, erythrocyte count, packecell volume, and hemoglobin level continue to decline steadily after patency. Once the parasites have been eliminated, increased hematopoiesis occurs, evidenced by the presence of nucleated erythrocytes, polychromasia, and anisocytosis [25].

\section{Biochemical findings}

Babesiosis infected cattle showed significant decrease in calcium and increase in phosphorus levels, this agree with [26,27] who noticed the serum changes may include increased potassium and reduced calcium and sodium levels. Babesiosis infected cattle showed significant increase in AST, hypoproteinemia, this may indicate the harmful effect of toxic metabolites of Babesia sp. on liver cells. These results were supported by [28]. Serum level of iron was significantly decreased $(\mathrm{P}<0.001)$, while copper showed insignificant change. The drop in serum level of iron may be due to anemia which leads to excessive withdrawal of serum iron to be utilized for erythropoeisis. While others have extremely high concentrations of serum iron [29].

Babesiosis infected cattle showed significant decrease in protein. Our present study indicates that the serum protein and globulin pattern was significantly altered by babesia bigemina infection. There was a significant decrease in total protein in serum of infected clinical cases and these in accordance with data recorded in cattle $[30,31]$, in calves by [32] and In buffaloes [33-35].

Concerning the effect of Babesia bigemina infection on activity of liver enzymes, the obtained results revealed a highly significant increase in serum AST and ALT. These results were I agreement with other previous studies reported by Allen \& Kuttler [36] Camacho et al [37]. The increase in enzymes activity may attribute to sever anemia that lead to hypoxic and toxic liver damages. Also massive hemolysis may occur which in conjunction with hypoxia may lead to hepatic cell degeneration and glomerular dysfunction leading to increase in AST, ALT and Bun, Allen \& Kuttler, [36].

\section{Control}

Babesiosis infected cattle is often only noticed at the onset of hemoglobinuria, when the disease is far advanced. Although therapy and transfusion will generally save an infected animal even at an advanced stage of the disease, it may continue to be severely debilitated for several months after recovery [25,3739]. Thus, for economic and animal welfare reasons, the best option is to prevent rather than treat infections.

\section{References}

1. Iseki H, Zhou L, Kim C, Inpankaew T, Sununta C et al. (2010) Seroprevalence of Babesia infections of dairy cows in northern Thailand. Vet Parasitol 170(3-4): 193-196. 
2. Aytuğ CN, Alaçam E, Görgül S (1990) Koyunve Keçi Hastalıkları ve Yetiștiriciliği İstanbul. Tüm-Vet HayvancılıkhizmetleriYayını Pp. 201202.

3. Ferrer D, Castellà J, Gutiérrez JF, Lavín S, Marco I (1998): Sero prevalence of Babesiaovis in Moufl on Sheep in Spain. J Wildl Dis 34(3): 637-639.

4. İmren HY, Şahal M (1991) Veteriner İçHastalıkları. Ankara. Feryal Mat baacıllk San. Ve Tic. Ltd Şti. pp. 207-208.

5. Popa E (1998) Ixodid Ticks - Vectors of Babesiosis in Animals in Romania. Revista Romana de Medicina Veterinara 8 (2): 61-67.

6. Yeruham I, Hadani A, Galker F, Avidar Y, Bogin E (1998) ClinicoPathological and Serological Studies of Babesia ovis in Experimentally Infected Sheep. Zentralbl Veterinarmed B 45(7): 385-394.

7. Mahmoud MS, Kandil OM, Nasr SM, Hendawy SH, Habeeb SM, et al. (2015) Serological and molecular diagnostic surveys combined with examining hematological profiles suggests increased levels of infection and hematological response of cattle to babesiosis infections compared to native buffaloes in Egypt. Parasit Vectors 8: 319-333.

8. Adham FK, Abd-El-Samie EM, Gabre RM, El-Hussein H (2009) Detection of tick blood parasites in Egypt using PCR assay, I-Babesia bovis and Babesia bigemina. Parasitol Res 105(3): 721-730.

9. Feldman BF (1981) Anemias Associated with Blood Loss and Hemolysis. Vet Clin North Am Small Anim Pract 11(2): 265-276.

10. Jain JJ (1986) Schalm's Veterinary Hematology. $4^{\text {th }}$ (edn.), Philadelphia, USA.

11. Mosqueda J, Olvera-Ramirez A, Aguilar-Tipacamu G, Canto GJ (2012) Current advances in detection and treatment of babesiosis. Curr Med Chem 19(10): 1504-1518.

12. Decaro N, Larocca V, Parisi A, Losurdo M, Lia RP, et al. (2013) Clinical bovine piroplasmosis caused by Babesia occultans in Italy. J Clin Microbiol 51(7): 2432-2434

13. Nagati HE (1947) Some new and rare records of piroplasmosis with a list of the species of Babesia and Theileria so far recorded from Egypt Vet Rec 59(11):145-147.

14. Schalm OW, Jain NC, Carroll EJ (1975) Veterinary Haematology. $3^{\text {rd }}$ (edn.), Philadelphia, USA.

15. Coles EA (1986) Veterinary Clinical Pathology $4^{\text {th }}$ (edn.), Sunders Compay, Philadelphia, USA.

16. Omar AOJ, Sadat M, Emam FA (2015) Determination of oxidative stress markers associated with Babesia Bigemina. Afr J Biotechnol Res 3(6):150-5.

17. Singh AP, Singla LD, Singh AA (2000) study on the effects of macroclimatic factors on the seasonal population dynamics of Boophilus micropus (Canes 1888) infesting the cross-bred cattle of Ludhiana district. Int J Anim Sci 15:29-31.

18. Fujinaga $\mathrm{T}$ (1981) Bovine Babesiosis in Japan: clinical and clinicpathological studies on cattle experimentally infected with Babesia ovata. Nihon Juigaku Zasshi 43(6): 803-813.

19. Georgi JR, Georgi ME, Theodrides VJ (1990) Parasitology for Veterinarians $5^{\text {th }}($ edn.), WB Saunders Company. Harcourt Brace Jovanovich Inc, Philadelphia, USA.

20. Pandy N, Misra S (1987) Haematological and Biochemical response to haemolyticanaemia of clinical Babesiosis in cattle and therapy. Ind Vet J 64: 882-886

21. Hussein AH, Mohammed NAES, Mohammed HK (2007) Theileriosis and babesiosis in cattle: haemogram and some biochemical parameters. ISAH-2007 Tartu, Estonia 143-150.
22. Riond BMM, Braun U, Deplazes P, Joerger K, Thoma R, et al. (2008) Concurrent infections with vector-borne pathogens associated with fatal anemia in cattle: hematology and blood chemistry. Comparative Clinical Pathology 17(3): 171-177.

23. Salem NY, Farag HS (2014) Clinical, hematologic, and molecular findings in naturally occurring Babesia canis vogeli in Egyptian dogs. Veterinary Medicine International 2014(2014): Article ID 270345, 6 pages.

24. Salem NY, El-Sherif MA (2015) Malondialdehyde status, trace minerals and hematologic results of anemic- T. equi infected Egyptian horses. Int J Vet Sci 4(3):118-122.

25. Lewis D, Purnell RE, Francis LM, Young ER (1981) The effect of treatment with imidocarbdipropionate on the course of Babesia divergens infections in splenectomised calves, and their subsequent immunity to homologous challenge. J Comp Pathol 91(2): 285-292.

26. O’Neill, AR (1983) Blood transfusions in the treatment of red water. Ir Vet News J.

27. Zintl A, Mulcahy G, Skerrett HE, Taylor SM, Gray JS (2003), Babesi adivergens, a Bovine Blood Parasite of Veterinary and Zoonotic Importance. Clin Microbiol Rev 16(4): 622-636.

28. Yeruham I, Avidar Y, Aroch I, Hadani A (2003) Intra-uterine infection with Babesia bovis in a 2-day-old calf. J Vet Med B Infect Dis Vet Public Health 50(2): 60-62.

29. Jerichow $\quad H, \quad$ Jungmann $\quad R \quad$ (1969) UntersuchungenzurSchadwirkungvonBabesiadivergens. 1 Mitteilung: der GehaltanKalium, Kalzium, MagnesiumundEisenimBlutserumbzwplasma beiklinischmanifester Piroplasmoseunter den Bedingungen der natürlichenInfektion. Monatsh. Veterinärmed 24: 732-736.

30. Ashmawy KRA, Mandour A, Korshom M (1994) Alteration in protein electrophoretic pattern glutathione redox system and trace.

31. Sharma A, Singla LD, Ashuma, Batth BK, Kaur P (2016) ClinicopathoBiochemical Alterations Associated with Subclinical Babesiosis in Dairy Animals. J Arthropod Borne Dis 10(2): 258-266.

32. Venu R, Sailaja N, Srinivasa Rao K, Jayasree N, Vara Prasad WL (2015) Babesiabigemina infection in a 14-day old Jersey crossbred calf: a case report. J Parasit Dis 39(2): 264-265.

33. Abd El-Maksoud HA, Ramadan MY, Abdel-Mageid AD (2005) Biochemical studies and haemolymph microscopy diagnosis of Babesia bovis infection in buffaloes with special reference to protein electrophoresis and alterations in serum fatty acid patterns. 4 intl Sci Conf, Mansoura, Egypt, pp: 1241-1256.

34. Werner LL, Turnwald GH, Willard MD (2004) Immunologic and plasma protein disorders. In: Willard MD \& Tvedten H (Eds.), Small animal clinical diagnosis by laboratory methods, pp. 290-305

35. Kerr MG (2002) Veterinary laboratory medicine clinical biochemistry and hematology. $2^{\text {nd }}$ (edn.), Cornwall: Blackwell Science, p.74-79.

36. Allen PC, Kuttler KL, Amerault TE (1981) Clinical chemistry of anaplasmosis: blood chemical changes in infected mature cows. Am J Vet Res 42(2): 322-325

37. Camacho AT, Guitian FJ, Pallas E, Gestal JJ, Olmeda AS, et al. (2005) Serum protein response and renal failure in canine Babesia annae infection. Vet Res 36(5-6): 713-722.

38. Barrera R, Carapeto MV Habela MA, Zaragoza C (2010) Electrophoresis pattern of serum in horses with babesiosis. Arch Med Vet 42(3): 173178.

39. Purnell RE, Young ER, Brocklesby DW, Hendry DJ (1977) The hematology of experimentally induced- $B$. divergens, and E. phagocytophila infections in splenectomised calves. Vet Rec 100(1):4-6. 


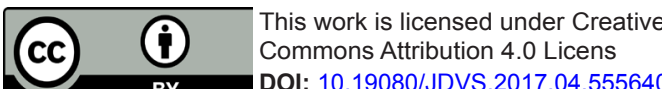
Commons Attribution 4.0 Licens

DOI: 10.19080/JDVS.2017.04.555640

\section{Your next submission with Juniper Publishers} will reach you the below assets

- Quality Editorial service

- Swift Peer Review

- Reprints availability

- E-prints Service

- Manuscript Podcast for convenient understanding

- Global attainment for your research

- Manuscript accessibility in different formats

( Pdf, E-pub, Full Text, Audio)

- Unceasing customer service

Track the below URL for one-step submission https://juniperpublishers.com/online-submission.php 